\title{
Formulation and Effectiveness Test of Matoa Stem (Pometia Pinnata) Skin Extract Cream Combination of Honey on Staphylacoccus Aureus Bacteria
}

\author{
Norma \\ Lecturer of Politeknik Kesehatan Kemenkes Sorong
}

\begin{abstract}
Matoa (Pometia Pinnata) is a typical Papua fruit plant, classified as a large tree with an average height of 18 meters with a maximum average diameter of $100 \mathrm{~cm}$. Generally bear fruit once a year, flowering in July to October and fruiting 3 or 4 months later. Some research shows that the leaves, fruit bark and matoa tree bark contain tannins, saponins and alkaloids. The purpose of this study was to produce a formulation and test the effectiveness of a cream extract of matoa tree bark (pometia pinnata) honey combination on staphylacoccus aureus bacteria. This research is a purely experimental research to produce an extract of the matoa tree bark cream and then test its effectiveness in the treatment of staphylococcus aureus bacteria, with a completely randomized design (CRD) design. The results showed that the matoa rind extract cream was effective against staphylacoccus aureus bacteria with a significant value of $0.00<0.005$. This study recommends a combination of honey bark stem extract cream for the treatment of staphylococcus aureus bacterial infections.
\end{abstract}

Keywords: Matoa, cream, extract and Staphylacoccus Aureus

\section{Introduction}

Matoa (Pometia pinnata) is a typical Papua fruit plant, classified as a large tree with an average height of 18 meters with a maximum average diameter of 100 $\mathrm{cm}$. Generally bear fruit once a year, flowering in July to October and fruiting 3 or 4 months later ${ }^{1}$.

Matoa grow in groups in certain places in the forest. Generally it grows naturally in flat textured soils when it rains a little inundated. In the fruiting season this tree can produce quite a number of fruits and if eaten the fruit tastes sweet so it is often referred to as the matoa fruit tree. Besides producing fruit, leaves, fruit bark and matoa tree bark can be used as medicine ${ }^{2}$.

Previous research conducted by Ngajow, Abidjulu, $\& \mathrm{Kamu},{ }^{3}$ with a concentration of 2 grams of matoa bark extract in $2 \mathrm{~mL}$ aquades, showed that the bark of matoa

\section{Corresponding author:}

\section{Norma}

Email Address: normaepid@gmail.com rods had a strong antibacterial effect on Staphylococcus aureus bacteria, each inhibition zone was obtained. 16.84 $\mathrm{mm}, 12.5 \mathrm{~mm}$ and $14.5 \mathrm{~mm}$ with positive controls 29.67 $\mathrm{mm}$ and negative controls $0 \mathrm{~mm}$. The results obtained are supported by the presence of secondary metabolites phytochemical test results, namely tannins, flavonoids, terpenoids and saponins.

Staphylococcus aureus is a pathogenic bacterium in humans that causes various clinical manifestations. Staphylococcus aureus lives on the skin and nasal membranes with great pathogenic potential to cause various infections ${ }^{4}$ It is a gram-positive bacterium with a diameter of 0.7-1.2 $\mu \mathrm{m}$ in diameter, arranged in irregular groups such as grapes, facultative anaerobes, does not form spores, and does not move. More than $90 \%$ of clinical isolates produce $\mathrm{S}$. aureus which have polysaccharide capsules or thin membranes that play a role in bacterial virulence.

Honey can help wound healing, because it contains antibacterial and antiseptic effects thanks to the hydrogen peroxide content. In addition, the $\mathrm{pH}$ of honey that is 
acidic (between 3.2-4.5) can inhibit bacterial growth. The addition of honey in cream preparations aims to help speed the healing of stapylacocus aures infections and its healing does not cause scars, because honey has anti-inflammatory effects and the ability to disguise scars. Honey accelerates repair of blood vessels (due to damage to blood vessels when injured), helps accelerate the growth of damaged skin layers, increases collagen which is very good to help repair skin, and prevents scars and keloids 5 .

The results of a preliminary study conducted by researchers in the community in the city of Sorong on the use of the matoa tree as a medicine, showed that the matoa tree, not yet used as a medicine by him, through this research will be produced formulations cream extracts of the matoa tree bark (pometia pinnata) effective honeybee combination against treatment of staphylacocus aureus bacterial infections.

\section{Materialsand Method}

This research is an in-vitro laboratory experimental study to produce matoa tree bark extract cream preparation and then test its effectiveness on the staphylococcus aureus bacteria, with a completely randomized design (CRD) design.

\section{Population and Samples}

The population in this study were all staphylococcus aureus bacteria raised in Nutrient Agar (NA) media. Samples are part of the staphylococcus aureus bacteria which are raised in the Nutrient Agar (NA) media. Using a diffusion technique with 3 treatments and 9 repetitions.

2. Materials and Tools

1) Material

The materials used in this study were matoa bark

Table 1. Evaluation Results of Matoa Stem Bark Extract Cream

\begin{tabular}{|l|l|l|}
\hline No & Evaluation Test & Evaluation Formulation Results \\
\hline 1 & Organoleptic Test & $\begin{array}{l}\text { Light brown color, characteristic odor of matoa tree bark, thick } \\
\text { consistency. }\end{array}$ \\
\hline 2 & Homogeneity Test & Evenly dispersed \\
\hline 3 & PH Test & 4,54 \\
\hline
\end{tabular}

extract, honey bee, glisein, sodium lauryl sulfate, methyl pareben, propyl paraben, cetyl alcohol, propylenglycol, glycerin monostearate, $\alpha$ tocopherol, alcohol, aquadest, nutrient agar, and Staphylococcus aureus and Broth nutrients.

2) Tools

The tools used in this research are mortar, stamper, funnel, porcelain cup, test tube, water bath, measuring cup, Erlenmeyer flask, dropper, cotton, stirring glass, stove, wood clamp, rotary evaporator, vaporizer cup, petri dish, maserator tubes, platinum plates, Beckham $\mathrm{pH}$ meters, Rion viscomometers, Memmert incubators.

\section{Data Analysis}

The purpose of data analysis is to test hypothetical: Data analysis of antibacterial activity was carried out by measuring the diameter of inhibitory regions using calipers in each intervention. Then statistical analysis using one-way ANOVA and Tukey's test, using SPSS.

The results of the analysis are concluded:

1) If rvalue $\leq a$, Ho is rejected, it means that Matoa Bark Extract Cream combination of honey is effective in staphylococcus aureus bacteria.

2) If rvalue $\geq a$, Ho fails to reject, it means that the combination of Madato Stem Matoa Bark Extract Cream is effective in staphylococcus aureus bacteria.

\section{Data Presentation}

\section{Results}

\section{A. Research Results}

1. Cream Evaluation Results 


\section{KHM Results}

Table 2. Test Results of Matoa Stem Skin Cream Extract Combination of Honey on Staphylacoccus Aureus Bacteria

\begin{tabular}{|c|c|c|c|c|c|c|c|c|c|c|c|}
\hline \multirow{2}{*}{ Bacteria Test } & \multirow{2}{*}{ Treatment } & \multicolumn{9}{|c|}{ Obstacle Zone (mm) } & \multirow{2}{*}{$\begin{array}{l}\text { Average } \pm \\
\text { Standard } \\
\text { Deviation }\end{array}$} \\
\hline & & R1 & $\mathbf{R 2}$ & $\mathbf{R 3}$ & R4 & R5 & R6 & $\mathbf{R 7}$ & R8 & R9 & \\
\hline \multirow{3}{*}{$\begin{array}{l}\text { Staphylacoccus } \\
\text { Aureus }\end{array}$} & Cream & 17 & 15 & 18 & 15 & 17 & 17 & 15 & 21 & 15 & $16,67 \pm 2,000$ \\
\hline & Extract & 17 & 15 & 17 & 17 & 17 & 16 & 18 & 14 & 17 & $16,44 \pm 1,236$ \\
\hline & Honey & 7 & 7 & 6 & 4 & 6 & 4 & 4 & 5 & 6 & $5,67 \pm 1,118$ \\
\hline
\end{tabular}

Table 2, shows that from nine times the repetition of matoa bark extract cream has an average value of 16, 67, a standard deviation of 2,000. Matoa bark extract has an average value of 16.44, a standard deviation of 1.236 and Honey has an average value of 5.67 and a standard deviation of 1.118 .

\section{Data Normality and Homogeneity Test}

Before the bivariate test, the data normality test and test are performed first homogeneity, presented in the following table:

Table 3. Data Normality Test

\begin{tabular}{|l|l|l|l|l|}
\hline \multirow{4}{*}{ Intervention } & \multirow{2}{*}{ Group } & Shapiro-Wilk & df & \multicolumn{2}{|l|}{ Sig. } \\
\cline { 3 - 5 } & & Statistic & 9 & 0,027 \\
\cline { 2 - 5 } & Cream & 0,929 & 9 & 0,056 \\
\cline { 2 - 5 } & Extract & 0,839 & 9 & 0,102 \\
\cline { 2 - 5 } & Honey & 0,863 & 9 & \multicolumn{2}{|l}{} \\
\hline
\end{tabular}

Based on the table above, the three interventions showed a significant value $>0.05$, meaning that the data is normally distributed.

Table 4. Homogeneity Test Results

\begin{tabular}{|l|l|l|l|}
\hline Levene Statistic & df1 & df2 & Sig. \\
\hline 1.184 & 2 & 24 & 0,323 \\
\hline
\end{tabular}

Based on the table above shows that a significant value of $0.323>0.05$, means the distribution of homogeneous data, because the data is normally distributed and homogeneous, then it is continued with the parametric statistical test, namely the one-way ANOVA test and the Tukey test. 
4. Effectiveness Test of Matoa Stem Bark Extract, Matoa and Honey Stem Bark Extract

Table 5. ANOVA Test Analysis Results

\begin{tabular}{|c|c|c|c|c|c|}
\hline Intervention & & & & & \\
\hline & Sum of Squares & Df & Mean Square & $\mathbf{F}$ & Sig. \\
\hline Between Groups & 711,630 & 2 & 355,815 & \multirow{3}{*}{157.492} & \multirow{3}{*}{0,000} \\
\hline Within Groups & 54,222 & 24 & 2,259 & & \\
\hline Total & 765,852 & 26 & & & \\
\hline
\end{tabular}

Based on the table above shows that a significant value of $0,000<0.05$, this means that the cream of matoa bark extract, matoa bark extract and honey are effective in inhibiting bacteria.

Table 6. Similarities and Differences in Intervention Group Average (Post-Hoc Test)

\begin{tabular}{|c|c|c|c|c|c|c|c|}
\hline \multicolumn{8}{|c|}{ Multiple Comparisons } \\
\hline \multicolumn{8}{|c|}{ Dependent Variable: Intervensi } \\
\hline & \multirow{2}{*}{ (I) Group } & \multirow{2}{*}{ (J) Group } & \multirow{2}{*}{$\begin{array}{l}\text { Mean Difference } \\
\text { (I-J) }\end{array}$} & \multirow{2}{*}{$\begin{array}{l}\text { Std. } \\
\text { Error }\end{array}$} & \multirow{2}{*}{ Sig. } & \multicolumn{2}{|c|}{ 95\% Confidence Interval } \\
\hline & & & & & & Lower Bound & Upper Bound \\
\hline \multirow{6}{*}{$\begin{array}{l}\text { Tukey } \\
\text { HSD }\end{array}$} & \multirow{2}{*}{ Cream } & Extract & .222 & .709 & .947 & -1.55 & 1.99 \\
\hline & & Honey & $11.000 *$ & .709 & .000 & 9.23 & 12.77 \\
\hline & \multirow{2}{*}{ Extract } & Cream & -.222 & .709 & .947 & -1.99 & 1.55 \\
\hline & & Honey & $10.778^{*}$ & .709 & .000 & 9.01 & 12.55 \\
\hline & \multirow{2}{*}{ Honey } & Cream & $-11.000^{*}$ & .709 & .000 & -12.77 & -9.23 \\
\hline & & Extract & $-10.778 *$ & .709 & .000 & -12.55 & -9.01 \\
\hline
\end{tabular}

Based on the table above, the average difference rate of inhibition of bacteria between cream and extract is $0.222 \mathrm{~mm}$, the lower and upper boundary values are -1.55 to 1.99 with a significant level of $0.947>0.05$, this indicates that there is no difference significant between the extraction of matoa rod bark extract with the matoa bark extract in inhibiting bacteria. While Cream and honey, the average difference rate is $11 \mathrm{~mm}$, the lower and upper limit values are 9.23 to 12.77 with a significant level of $0.00<0.05$, this indicates that there is a significant difference between the bark extract cream creams matoa with honey in inhibiting bacteria.

\section{Discussion}

Matoa bark contains alkaloids, triterpenoids, 
steroids, flavonoids, saponins and tannins, which have anti-bacterial properties, from the results of research conducted by Ngajow et al., ${ }^{3}$ about the anti-bacterial influence of extracts of the bark of the stem skin (Pometia Pinnata) against bacteria staphylococcus aureus from three repetitions carried out by the widest bacterial inhibition with an average diameter of $16.84 \mathrm{~mm}$ with strong disinfecting properties (susceptible bacteria).

The results of the study were then developed in the form of a honeycomb combination of sunflower bark extract. Cream composition consists of preservative combination of methyl paraben as much as $0.3 \mathrm{~g}$ and propyl paraben as much as $0.3 \mathrm{~g}$. The oil phase used is $1.8 \mathrm{ml}$ of glycerin as much as $1 \mathrm{ml}$ of antioxidant $\alpha$ tocopherol as much as $1 \mathrm{ml}$, and as much as $5 \mathrm{~g}$ of cetyl alcohol which is also soluble in the oil phase. Sodium lauryl sulfate as much as 5 grams and propilenglycol as much as 1 gram are the water phases then both phases are heated to a temperature of $65^{\circ} \mathrm{C}$ above the water bath. Then the two phases are put in a stirrer, stirring to form a cream mass. Then propyl and methyl paraben are added to the preparation after first dissolving it in $1 \mathrm{ml}$ of warm water. After a cold base, $1 \mathrm{~g}$ of honey is added then the cream is placed in a geometric stirer and stirred until homogeneous and stirring is continued for 15 minutes until the cream is completely homogeneous.

Cream evaluation (Table 1.), shows the results of the organoleptic test of light brown color, the characteristic odor of matoa stem bark with thick consistency. The homogeneity of the uniformly dispersed cream with a $\mathrm{pH}$ of 4.54 is safe for the skin, which is between 4.2 - 5.6. The results of the light brown color comes from the skin color of the stem, the thickness due to the thickening agent used is cetyl alcohol. Thickening is a thickener that functions as a binder to the oil phase and water phase associated with Hydrophilic Lipophyll Balance (HLB). Thickening agents or thickening agents are used to regulate the thickness of the product so that it is suitable for the purpose of using the cream and maintain the stability of the product ${ }^{7}$.

According to Rowe et al. in Udayana et al., ${ }^{7}$ the concentration of cetyl alcohol for sttifening agents ranged from $2-10 \%$. In this optimization, a concentration of $5 \%$ cetyl alcohol is chosen. After the formulation process, the evaluation of the preparations is carried out in order to maintain the quality of the preparations that have been produced. Performed a physical evaluation On the homogeneity test, the results showed that the preparation has good homogeneity because there are no visible particle granules.

After the cream preparation test is carried out, then followed by staphylococcus aureus bacterial inhibition test using a combination of honeycomb stem skin extract, as a control is the extract of matoa bark and honey. The repetition is done nine times for each intervention.

Based on the results of the Analysis of Variance (ANOVA) shows (table 5) that the significance value is $0.00<0.05$. This means that the matoa bark extract cream, matoa bark extract and honey are effective in inhibiting bacteria.

The mechanism of action of flavonoids as antibacterial is to form complex compounds with extracellular protein and dissolved so that it can damage the bacterial cell membrane and followed by the release of intracellular compounds. In addition to playing a role in inhibition of DNA - RNA synthesis by intercalation or hydrogen bonding with a buildup of nucleic acid bases, flavonoids also play a role in inhibiting energy metabolism. This compound will disrupt energy metabolism in a way similar to inhibiting the respiratory system, because it requires sufficient energy for the active absorption of various metabolites and for macromolecular biosynthesis ${ }^{3}$.

The terpenoid compounds are also known to be active against bacteria, but the antibacterial mechanism of triterpenoids is still not really known. The terpenoid antibacterial activity is thought to involve membrane breakdown by lipophilic components. In addition, according to ${ }^{3}$ phenolic compounds and terpenoids have the main target of cytoplasmic membrane which refers to its hydrophobic nature. The mechanism of action of saponins as an antibacterial is to reduce surface tension resulting in increased cell permeability or leakage and cause intracellular compounds to come out. These compounds diffuse through the outer membrane and cell walls of the vulnerable, then bind to the cytoplasmic membrane and disrupt and reduce that stability.

Similarities and differences in the mean of the intervention group are shown by the results of Tukay's 
analysis (Table 6). The average difference rate of bacterial inhibition between cream and extract is 0.222 $\mathrm{mm}$, the lower and upper limit values are -1.55 to 1.99 with a significant level of $0.947>0.05$, this shows that there is no significant difference between extract creams Matoa bark extract with Matoa stem bark in inhibiting bacteria. While Cream and honey, the average difference rate is $11 \mathrm{~mm}$, the lower and upper limit values are 9.23 to 12.77 with a significant level of $0.00<0.05$, this indicates that there is a significant difference between the bark extract cream creams matoa with honey.

The difference in inhibition between cream combination of matoa stem bark combination of honey with matoa bark extract caused by the addition of cream and honey ingredients gives an average difference of $0.222 \mathrm{~mm}$ even though the difference is not significant. The strength of the basic ingredients of the bark of the matoa stem, namely alkaloids, triterpenoids, steroids, flavonoids, saponins and tannins, is very dominant in inhibiting the bacterium Staphylococcus aureus.

The difference of inhibitory power between honey and honey matoa stem bark extract cream was $11 \mathrm{~mm}$, showing significant results. Differences in the content of each intervention cause differences in inhibition.

While research conducted by Sulastri \& Sari, ${ }^{7}$ lauric acid cream preparations tested on staphylococcus aureus bacteria showed antibacterial activity by forming inhibitory diameters for concentrations of $10 \%, 20 \%$ and $30 \%$. The inhibitory diameters were $10.479 \mathrm{~mm}, 14.8$ $\mathrm{mm}$, and $21.589 \mathrm{~mm}$, respectively.

The highest inhibitory zone of honey extract combined with honey is in the 8th loop (R 8) of $21 \mathrm{~mm}$ (Table 4) when compared with research conducted by Sulastri \& Sari, ${ }^{7}$ the highest inhibitory zone of lauric acid cream is 21,589 . Although there is a difference of $0.589 \mathrm{~mm}$, but both creams have a very strong inhibition against staphylococcus aureus bacteria. The inhibition zone formed $\geq 20 \mathrm{~mm}$ is considered to have very strong inhibitory activity, $10-20 \mathrm{~mm}$ is stated to have strong inhibitory activity, $5-10 \mathrm{~mm}$ is stated to have moderate inhibitory activity and $\leq 5 \mathrm{~mm}$ is stated to have weak inhibitory activity ${ }^{9-12}$.

Ethical Clearance: from university ethical committee
Source of Funding : This publication was supported by the Health Polytechnic Ministry of Health, Sorong, Indonesia.

\section{Conflict of Interest : Nil}

\section{References}

1. Raodah, S., \& Kadir, S. Tanaman Khas Papua: Matoa, (49). Retrieved from https://www.google. com/url?sa $=\mathrm{t} \quad \& \mathrm{rct}=\mathrm{j} \& \mathrm{q}=\quad \& \mathrm{esrc}=\mathrm{s} \&$ source $=$ web\&cd $=\quad 1 \&$ ved=2ahUKEwi GucH0sHiAh We6nMBHZTiDE0QFjAAegQIABAC\& url= http $\% 3 \mathrm{~A} \% 2 \mathrm{~F} \% 2 \mathrm{~F}$ papua.litbang.pertanian. go.id\%2Findex.php\%2 Fpublikasi\%2 Fbuku\%3 Fdownload\%3D12\%3 Abuku-seri-matoa\&usg= AOvVaw1 VdR1DnezECb Ki0GDp3. 2014.

2. Nishihara, A. A. (2017). PENGARUH HAND SANITIZER KULIT BUAH MATOA (Pometia pinnata) TERHADAP ANGKA BAKTERI GRAM NEGATIF ISOLAT TANGAN, 117.

3. Ngajow, M., Abidjulu, J., \& Kamu, V. . Pengaruh Antibakteri Ekstrak Kulit Batang Matoa ( Pometia pinnata ) terhadap Bakteri Staphylococcus aureus secara In vitro. Jurnal MIPA UNSRAT, 2014; 2(November 2013), 128-132.

4. D A Aldeen, K Hiramatsu. Staphylococcus Aureus 'Molecular and Clinical Aspects' University Hospital, Nottingham, UK and University Of Juntendo, Japan. https://www.elsevier.com/books/ staphylococcus-aureus/aldeen/978-1-898563-96-9. Akses Januari 2020.

5. Ivena, O., \& Savitri, T.. Segudang Manfaat Madu Murni , dari Merawat Kulit Sampai Mencegah Maag. Retrieved from https://hellosehat.com/ hidup-sehat/tips-sehat/manfaat-madu-murni/ 2017

6. Udayana, J. F., Samirana, P. O., \& Unud, J. K. Optimasi Formula Krim Ekstrak Rimpang Kunyit ( Curcuma domestica ) dengan Variasi Konsentrasi Setil Alkohol sebagai Agen Pengental, 2019; 7(2), 40-44.

7. Sulastri, E., \& Sari, A. K. UJI AKTIVITAS ANTIBAKTERI KRIM ASAM LAURAT TERHADAP Staphylococcus aureus ATCC 25923 DAN Pseudomonas aeruginosa ATCC 27853 ( ANTIBACTERIAL ACTIVITY TEST OF LAURIC ACID CREAM AGAINST Staphylococcus aureus ATCC 25923 AND Pseudomonas aeruginosa ATCC 27853 ). 2016. 
8. Ancela Rabekka Lingga1, U. P. and E. R. UJI ANTIBAKTERI EKSTRAK BATANG KECOMBRANG (Nicolaia speciosa Horan) TERHADAP Staphylococcus aureus DAN Escherichia coli ANTIBACTERIAL, 2016; 2(2). Retrieved from https://media.neliti.com/media/ publications/186658-ID-none.pdf

9. Endah Yani, R.W., Mallongi, A., Andarini, S., Prijatmoko, D., Dewanti, I.R. The effect of zinc saliva on the toddlers' nutritional status. Journal of International Dental and Medical Research, 2016, Volume 9, Issue 1, Pages 29-32

10. Russeng, S.S., Saleh, L.M., Virani, D., Latief, A.W.L., Mallongi, A. The investigation of the lactic acid change among employee of national electrical power plan. Indian Journal of Public Health Research and Development 2018; Volume 9, Issue 1, Pages 361-365

11. Birawida, A.B., Selomo, M., Mallongi, A. Potential hazards from hygiene, sanitation and bacterium of refill drinking water at Barrang Lompo island (water and food safety perspective) IOP Conference Series: Earth and Environmental Science 2018; Volume 157, Issue 1, Article number 012034

12. Mallongi, A., Parkpian, P., Pataranawat, P., Chinwetkitvanich, S. Mercury distribution and its potential environmental and health risks in aquatic habitat at artisanal buladu gold mine in Gorontalo Province, Indonesia. Pakistan Journal of Nutrition, 2015; Volume 14, Issue 12, Pages 1010-1025 